\title{
Relationship of Principal Leadership Style, Teacher Work Culture, Teacher Competency, Teacher Job Satisfaction and Performance of Special School Teachers in Banjarbaru City
}

\author{
Betya Sahara*, Ahmad Suriansyah, Ngadimun \\ Master Program of Educational Management, Universitas Lambung Mangkurat, Banjarmasin 70123, \\ Indonesia
}

\section{Article history:}

Submission October 2020

Revised January 2021

Accepted January 2021

${ }^{*}$ Corresponding author:

E-mail:

betyasahara@gmail.com

\begin{abstract}
Performance is any process that can benefit organizations that produce quantity and quality, copyright, ease, and speed in self-adjustment. The principal's leadership style, work culture, teacher competency, job satisfaction allegedly affect the teacher's performance. This research aims to describe the influence of the principal's leadership style, work culture, teacher competency, and job satisfaction on teacher performance in special schools in Banjarbaru City. This research is a quantitative study using regression techniques with five variables, namely principal leadership style (X1), work culture (X2) as a free variable, teacher competency (Z1), job satisfaction (Z2) as an intervening variable (between variables), and teacher performance (Y) as bound variables. The data were collected through a questionnaire from 86 samples. Data analysis was conducted using the SPSS 24 for windows. The results showed a significant influence between the principal's leadership style, work culture, teacher competency, and job satisfaction in Banjar Baru special schools. This research recommends that teachers be more active and creative to improve their performance and create a great organizational culture.
\end{abstract}

Keywords: Principal leadership, work culture, teacher competency, job satisfaction

\section{Introduction}

Performance is the acquisition of an employee's work following the organization's objectives. Performance can be defined as any process that can benefit the organization, including the vision, mission, and purpose of an organization that produces quantity and quality, copyright, ease, and speed in self-adjustment (Brahmasari \& Suprayetno, 2008).

The level of satisfaction of the teacher can have an impact on his performance and the institution in which he or she works because the teacher is the principal in education in the school; Robins (2006) describes several factors that affect job satisfaction, including (a) challenging work; (b) proper salary or wages; (c) working conditions; and (d) supportive associates. Besides, teachers need to demonstrate high performance so that it is expected to increase job satisfaction. Luthans (2006) measures five aspects of job satisfaction with the Job Descriptive Index (JDI), namely the work itself (related to responsibility, interests, and growth; quality of supervision (related to technical assistance and social support); relationships with colleagues (relating to social harmony and respect); promo-tional opportunities (relating to further devel-opment opportunities); and payments (relating to adequate pay and perception of fairness). In addition to competency factors, there are factors related to teacher performance and job satisfaction, 
namely the principal's work culture and leadership style. Organizational culture is a mutual agreement on the organization's values shared and binds all relevant organizations. This culture will play a role in determining the structure and various operating systems that produce norms, regulations, and how interactions are in an organization.

According to Suryani (2013), the organizational culture grows because it is created and developed by individuals working within an organization, and is accepted as values that must be maintained and passed down to each new member. These values are used as guidelines for each member as long as they are in the organization's environment and are considered typical cirri that distinguish an organization from another. While the principal's leadership is situa-tional, leadership can be effective for certain situations and less effective for other situations.

Leadership will determine direction, objectives, guidance, and create a climate and work culture that supports the implementation of institutional and administrative processes as a whole. Leadership mistakes can lead to the agency failing to carry out its mission. As a leader in his ward, the principal is obliged to carry out administrative tasks and concerns about how to organize the entire school program. He should lead and direct aspects of both administrative and educational processes in his school so that the school he leads becomes dynamic and dialectical. Effective and efficient school management is not separated from the principal's duties and functions, creating a work culture that can create a learning process and an ideal work atmosphere for teachers.

Performance as behaviors or actions are relevant to the achievement of organizational objectives (Heslin et al., 2005), the higher the teacher's performance, the higher the competence and emotional intelligence of the teachers. While Herman (2001) concluded a positive and significant influence between The Teacher's professional competencies on Teacher Performance by 26.8\%. Research by Chamundeswari (2013) on job satisfaction and teacher performance results is significantly correlated and positive. Research by Baroroh
(2013) shows there is a very significant positive relationship between job satisfaction and employee performance, which means that the higher the job satisfaction, the higher the level of employee performance

The principal's leadership style, work culture, teacher competence, and job satisfaction are alleged to influence school performance. Based on this, the author is interested in discussing and pouring in the form of a thesis titled "Influence of Headmaster Leadership Style, Work Culture, Teacher Competency, and Job Satisfaction on Teacher Performance in Special Schools in Banjarbaru City. This research aims to determine and analyze the influence of the principal's leadership style, work culture, teacher competency, and job satisfaction on teacher performance in special schools in Banjarbaru City.

\section{Material and Methods}

This research is a quantitative study using regression techniques with five variables, namely principal leadership style (X1), organizational culture (X2) as a free variable, teacher:

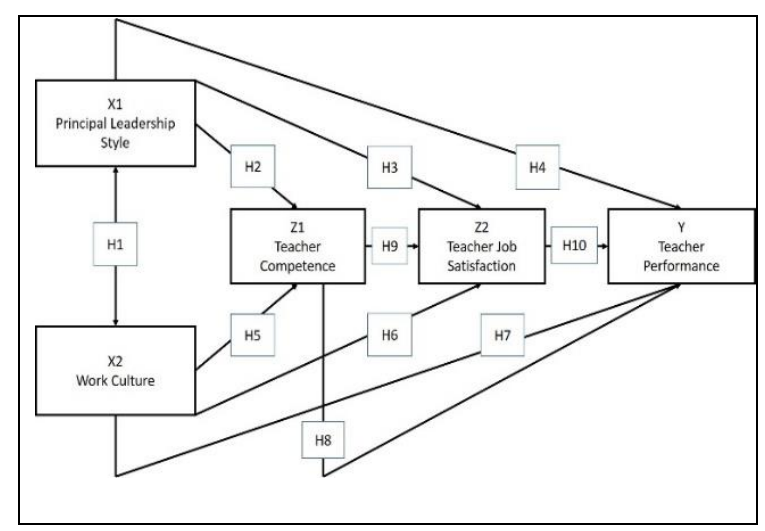

Figure 1. Research design

This research was conducted in 2 special schools or outstanding schools in Banjarbaru City, with 112 teachers who have the characteristics of potential students, teachers, and principals who are almost evenly distributed. Research sampling is done by a proportional random sampling technique, which explains variables bound (dependent variables) (Y) variables that are affected by free variables. The sample's determination refers to the table Kreiche and 
Morgan (Sekaran, 2006) and for a population score of 112, a sample of 86 people.

\section{Results and Discussion \\ Characteristic of Respondent}

The correspondent's age is dominated by the age range of $31-40$, which is $57 \%$, while for the last education level controlled by S1 as much as $79 \%$, with $92.3 \%$ coming from the education department. The most teaching experience is over five years under ten years. Certification status has a dominance rate on non-certification or does not yet have an educator certificate of $69.2 \%$, but $64.8 \%$ is already a civil servant or called ASN.

\section{Research Trials}

The Variable Hypothesis Testing instrument in this study is divided into free variables and bound variables. These variables are tested in validity and reliability tests.

\section{Validity test}

The validity test is conducted through SPPSS 24 application using the significant 0.05 . Instruments can be said to be reliable when the value of Cronbach alpha is greater than $r$ table. Based on the results of the instrument validity test conducted, it is concluded that the instrument used in the study is valid.

\section{Reliability test}

The reliability test is conducted through SPPSS 24 application using the significant 0.05 . Instruments can be said to be reliable when the value of Cronbach alpha is greater than $r$ table. Based on the results of the instrument reliability test conducted, it was concluded that the instrument used in the research reliable.

\section{Testing requirments analysis Normality test}

The normality test is performed using the SPSS 24 computer program. Normality test results with Normal P-P Plot indicate that probability numbers are around linear or straight lines. Data output is $0.064>0.05$ so that $\mathrm{H} 1$ is received, which means normally distributed data. This means that all variables that affect

research performance have normally distributed random data, so further statistical testing can be performed.

\section{Linearity test}

Linearity tests are performed using the ANOVA table. The linearity test of teacher performance influence $(\mathrm{Y})$ on the principal's leadership style (X1), linearity test of teacher performance influence $(\mathrm{Y})$ over teacher work culture (X2), Teacher performance influence linearity test (Y) on teacher competency (Z1), and Linearity test of the influence of teacher performance (Y) on teacher job satisfaction (Z2), obtained sig score results. Linearity data is all greater than 0.05 . So, it can be concluded that there is a relationship between the two variables, and the relationship is a linear, addictive, and causal relationship.

\section{Homogeneity test}

Homogeneity tests are performed using the SPSS 24 program. Output all data variables $>$ 0.05 so that $\mathrm{H} 1$ is received, which means the data is obtained from a homogeneous sample.

\section{Multicollinearity test}

Uji multicollinearity aims to test whether the regression model found the absence of correlations between independent variables. From the results of processing the test data, SPSS 24.0 can be concluded that there is no multicollinearity because the data shows that the value of VIF $<10.00$ so that there is no Multicholinearity to the data tested.

\section{Heteroskedastisity test}

Heteroscedasticity tests were conducted to test whether, in the regression model, there was a variance mismade from residual one observation to another. Based on scatterplot output, it is concluded that the spread of the dots already meets the conditions. This means there is no heteroskedasticity problem, so a good and ideal regression model can be met.

\section{Hypothesis test}

Simple regressions test

Before performing path analysis, the authors first performed a correlation analysis through the Windows SPSS program Version 
24 to find out the nature of the relationship between each variable studied. The results of the correla-tion analysis are as follows:

Table 1. A correlation analysis through the Windows SPSS program Version 24

\begin{tabular}{ccc}
\hline Relation & Correlation & Characteristic of Relationship \\
\hline X1 with X2 & 0.550 & Strong, Positive, Significant \\
X1 with Y & 0.475 & Strong, Positive, Significant \\
X2 with Y & 0.718 & Really Strong, Positive, Significant \\
X1 with Z1 & 0.354 & Really Strong, Positive, Significant \\
X2 with Z1 & 0.783 & Really Strong, Positive, Significant \\
Z1 with Y & 0.770 & Really Strong, Positive, Significant \\
Z2 with Y & 0.664 & Really Strong, Positive, Significant \\
X1 with Z2 & 0.319 & Strong, Positive, Significant \\
X2 with Z2 & 0.709 & Really Strong, Positive, Significant \\
Z1 with Y & 0.850 & Really Strong, Positive, Significant \\
Z1 with Z2 & 0.770 & Really Strong, Positive, Significant \\
\hline
\end{tabular}

\section{Path analysis}

Path analysis is an extension of multiple linear regression analysis or regression analysis to measure causality relationships between variables.

Direct Relationship of Principal Leadership Style (X1), Work Culture (X2), Influencing Teacher Competency (Z1)

Based on the results of the regression output on the coefficient table, it can be known that the signification values of both variables are $\mathrm{X} 1$ $=0.816$ and $\mathrm{X} 2=0.000$. The result of one of the significances of both variables is smaller than 0.05 . This result concludes that in Variable Regression, $\mathrm{X} 1$ has a low affect, and X2 has a significant effect on Y. Furthermore, the value of $\mathrm{R}$ Square obtained on the Model Summary table is 0.613 . This indicates that the contribution or contribution of $\mathrm{X} 1$ and $\mathrm{X} 2$ influences to $\mathrm{Z} 1$ is $61.3 \%$ of the remaining affected by other variables not included in the study.

Direct Relationship of Principal Leadership Style (X1), Work Culture (X2) influence Job Sat-isfaction (Z2)

Based on the result of the regression output on the coefficient table, it can be known that the signification values of both variables are $\mathrm{X} 1=$ 0.468 and $\mathrm{X} 2=0.000$. The result of the significance of both variables is smaller than 0.05 . This result concludes that in variable regression $\mathrm{X} 1$ and $\mathrm{X} 2$ have a significant effect on Y. Subse-quently, the value of $\mathrm{R}$ Square obtained on the Model Summary table is 0.495 . This indicates that the contribution or contribution of $\mathrm{X} 1$ and $\mathrm{X} 2$ influences to $\mathrm{Y}$ is $50.6 \%$ of the remaining $50.6 \%$ influenced by other variables not included in the study.

Direct Relationship of Principal Leadership Style (X1), Work Culture (X2) Affects Teacher Performance ( $Y$ )

Based on the results of the regression output on the coefficient table, it can be known that the signification values of both variables are $\mathrm{X} 1$ $=0.597$ and $X 2=0.000$. The result of one of the significances of both variables is smaller than 0.05 . This result concludes that in Variable Regression, $\mathrm{X} 1$ has a low effect, and X2 has a significant effect on Y. Furthermore, the value of $\mathrm{R}$ Square obtained on the Model Summary table is 0.517 . This shows that the contribution or contribution of $\mathrm{X} 1$ and $\mathrm{X} 2$ influences to $\mathrm{Y}$ is $51.7 \%$ of the remaining $51.7 \%$ influenced by other variables not included in the study. 
Indirect Relationship of Principal Leadership Style (X1), Work Culture (X2) Affects Job Satisfaction (Z2) Through Teacher Competency (Z1)

Based on the output result on the coefficient table, it can be known that the signification values of the three variables are $\mathrm{X} 1=$ $0.338, \mathrm{X} 2=0.010$, and $\mathrm{Z} 1=0,000$. The significant result between 3 variables is smaller than.05. These results suggest that in these regressions, variables $\mathrm{X} 1, \mathrm{X} 2$, and $\mathrm{Z} 1$ have a significant effect on Z2. Furthermore, the R Square value obtained in the Model Summary table is 0.626 . This shows that the contribution or contribution of $\mathrm{X} 1, \mathrm{X} 2$, and $\mathrm{Y}$ influences to $\mathrm{Z}$ is $62.6 \%$ of the remaining $62.6 \%$ influenced by other variables not included in the study.

Indirect Relationship of Teacher Competency (Z1) Affects Teacher Performance (Y) Through Job Satisfaction (Z2)

Based on the output result on the coefficient table, it can be known that the signification values of the three variables are $\mathrm{Z} 1=0.000$ and $\mathrm{Z} 2$ $=0.738$. The result of the significance of one of the variables is smaller than 0.05 . This result concludes that in the regression, the variable $\mathrm{Z} 1$ has a significant effect, and Z2 has a weak effect on Y. Furthermore, the value of R Square obtained on the Summary Model table is 0.772. This indicates that the contribution or contribution of $\mathrm{Z} 1$ and $\mathrm{Z} 2$ influences to $\mathrm{Y}$ is $77.2 \%$ of the remaining $77.2 \%$ influenced by other variables not included in the study.

Principal's Indirect Relationship (X1), Work Culture (X2) Affects Teacher Performance (Y) Through Teacher Competency (Z1) and Job Satisfaction (Z2)

Based on the output result on the coefficient table it can be known that the signification values of the three variables are $\mathrm{X} 1=$ $0.628, \mathrm{X} 2=0.148 \mathrm{Z} 1=0.000$ and $\mathrm{Z} 2=0.937$. Multiple significant results of variables are smaller than 0.05 . This result in the regression, variable Z1, has a significant effect, and X1.X2 and $\mathrm{Z} 2$ the $\mathrm{r}$ square value found on the Model Summary table is 0.730 . This indicates that the contribution or contribution of X1, X2, Z1, and $\mathrm{Z} 2$ influences to $\mathrm{Y}$ is $73 \%$, the remainder is influenced by other variables not included in the study.

Table 2. The dependent variable of teacher performance $(\mathrm{Y})$

\begin{tabular}{|c|c|c|c|c|c|c|}
\hline \multicolumn{7}{|c|}{ Coefficients } \\
\hline \multirow{2}{*}{\multicolumn{2}{|c|}{ Model }} & \multicolumn{2}{|c|}{$\begin{array}{l}\text { Unstandardized Coeffi- } \\
\text { cients }\end{array}$} & \multicolumn{3}{|c|}{$\begin{array}{l}\text { Standardized } \\
\text { Coefficients }\end{array}$} \\
\hline & & B & Std. Error & Beta & $\mathrm{t}$ & Sig. \\
\hline \multirow[t]{5}{*}{1} & (Constant) & 12.629 & 5.254 & & 2.404 & .018 \\
\hline & Leadership Style (X1) & .023 & .046 & .027 & .487 & .628 \\
\hline & Work Culture (X2) & .138 & .095 & .137 & 1.461 & .148 \\
\hline & Teacher Competence (Z1) & .627 & .087 & .747 & 7.207 & .000 \\
\hline & Job Satisfaction (Z2) & .011 & .140 & .007 & .079 & .937 \\
\hline \multicolumn{7}{|c|}{$\begin{array}{l}\text { The influence between Principal's Leader- } \\
\text { ship Style and Work Culture } \\
\quad \text { Based on the regression analysis results, } \\
\text { the influence of the Principal Leadership Style } \\
\text { with the working culture of outstanding school } \\
\text { teachers in Banjar Baru city. This can be seen } \\
\text { from the large correlation of } 0.050 \text { with a sig- } \\
\text { nificant level of } 0.000<0.05 \text {, then H0 rejected, } \\
\text { which means there is a positive and significant }\end{array}$} \\
\hline
\end{tabular}


line with research by Djafri (2020) that the implementation of a good leadership style and following the condition of the school will provide a more conducive school management, where the school's residents consciously and responsibly carry out their work so that what the school aspires to realize. Organizations with a strong and positive culture will allow teachers to feel motivated or changed to better develop, learn, and improve.

If teachers work in well-managed organizations will have higher motivation and satisfaction according to previous researches (Lubis, 2016; Dhafri, 2020; Ridho et al., 2016; Normianti et al., 2019; Turan \& Bektas, 2013; Kalkan et al., 2020; Xenikou, 2017; Tsay, 2011; Dalle et al., 2010).

\section{The influence between Principal Leadership Styles on Teacher Performance}

Based on the results of the regression analysis, it shows the influence of the Principal Leadership Style with the outstanding performance of school teachers in Banjar Baru city. This can be seen from the correlation size of 0.075 with a significant level of $0.000<0.05$, then $\mathrm{H} 0$ rejected, which means there is a positive and significant influence between the leadership style of the principal and the work culture. The analysis shows that the appropriateness between the principal's leadership style and the teachers' personal will have a good influence on the teacher's performance because the principal's leadership style will determine the performance of the person in the principal's leadership environment.

Dekawati (2011) Outlining factors that affect teacher performance include teacher education level, teaching supervision, management program, conducive climate, facilities, and infrastructure, teacher physi-cal and mental condition, principal leadership style, welfare guarantee, principal managerial ability, and others. According to Sujarwo (2012) states that the success of character formation will be determined not only in the power of learning but also by the power of management in the school's transport or-ganizational unit. The power of management depends heavily on the quality and strength of the principal as a leader.
The results of this study are also supported by the subsequent: Taufiq et al. (2016); Rafiie et al. (2018), Saputra et al. (2015); Gusman (2014); Su-priadi (2014); Adriana (2014); Bogler (2001); Shamaki (2015); Tambingon (2018) which revealed the results of the same research on the influence of leadership styles with teacher performance.

\section{The Influence between Teacher Work Culture and Teacher Performance}

Based on the results of regression analysis shows the influence of Teacher Work Culture on the performance of outstanding school teachers in Banjar Baru city. This can be seen from the correlation size of 0.718 with a significant level of $0.000<0.05$, then $\mathrm{H} 0$ rejected, which means there is a positive and significant influence between teacher work culture on teacher performance. An unconducive organizational culture and low employee motivation can result in low employee performance in the community. Organizational culture forms some functions within an organization, namely: (1) culture have a role in establishing a poultice of boundaries, meaning that culture creates a clear difference between one organization of another, (2) culture brings a sense of identity to members of the organization, (3) culture facilitates the onset of commitment to a wider area than one person's interests, (4) culture can improve the stability of the system, (5) culture serves as a mechanism of meaning creation and control that guides and shapes employee attitudes and behaviors (Robins, 2006). This research result is also supported by other researchers, such as Arianto (2013), Artaida (2013), Setiyati (2014); Taufiq et al. (2016); Adha et al. (2019); Talimbo (2013); Basri (2017); Purwoko (2018); Ghaney et al. (2017), Hutabarat (2015); Gemafle et al. (2018) the results of the same research on the influence of work culture with teacher performance.

\section{Influence of Principal Leadership Style on Teacher Competency}

Based on the regression analysis results above, it shows the influence of the Principal's Leadership Style on the competence of outstanding school teachers in Banjar Baru city. This can be seen from the correlation of 0.54 
with a significant level of $0.000<0.05$ and the correlation result of $<0.05$ ), then $\mathrm{H} 0$ rejected, which means there is a positive and significant influence between the Principal's Leadership Style on Teacher Performance. With one's awareness and willingness to obey all regulations, it is expected that the employee in question will improve his performance. Thus, the Work Culture must be enforced in an organization or institution. The results of this study are also supported by the subsequent: Banani (2017); Resawati \& Larasati (2016) Nurman et al. (2018), Mahri (2014), Khoirun (2020), Wahyudin (2017), Rahardjo (2014), Gobler et al. (2012) which presents similar results in research on the influence of leadership with teacher competency.

\section{The influence between Teacher Work Cul- tures on Teacher Competency}

Based on the regression analysis results, the influence of the principal's leadership style on the competence of outstanding school teachers in Banjar Baru city. This can be seen from the correlation size of 0.783 with a significant level of $0.000<0.05$ and the correlation result of " 0.05 " than $\mathrm{H} 0$ rejected, which means there is a positive and significant influence between the Teacher Work Culture on Teacher Competency. As stated by Mangkunegara (2005) defines that Work Culture is a set of assumptions or belief systems, values, and norms developed within the organization that serves as a code of conduct for its members to address the problem of external adaptation and internal integration. The results of this study are also relevant to the research from Pakpahan, Simanjutak, Nababan, \& Sudirman (2019), Miyono \& Makshun (2017), Arifin (2015), William (2005), Afandi \& Supeno (2016), and Sari (2013) about the influence of work culture on teacher work competencies.

\section{The influence between Teacher Competen- cies on Teacher Job Satisfaction}

Based on the regression analysis results above, it shows the influence of teacher competence on the job satisfaction of outstanding school teachers in Banjar Baru city. This can be seen from the correlation size of 0.770 with a significant level of $0.000<0.05$ and the correlation result of $<0.05$ ), then $\mathrm{H} 0$ rejected, which means there is a positive and significant influence between teacher competency on teacher job satisfaction. Teachers are the spearhead of educational success, so it is necessary to make improvement efforts both internally and externally to understand and address the basic competencies required in the learning process and the corridors of the existing curriculum (Narsih, 2017). Job satisfaction and teacher competency are strategic factors in the development of education. Teachers who become agents of change in schools are expected to be role models in Indonesian education advancement. In the absence of qualified teachers, it cannot be achieved the Indonesian nation's ideals in pursuing the lag of other nations. Indonesia is a nation that has a noble culture in achieving the prosperity and well-being of its people. Based on the above discussion can be concluded: 1) There is no influence of teacher competence on performance; 2 ) There is a significant influence between work satisfaction and performance, and 3) There is an influence of teacher competence and job satisfaction together with the influence on performance. The results of this study are also in line with the research from Sari (2013); Tafqihan \& Suryanto (2014); Akram et al. (2015); Sel (2012), Shukla (2014), Sing \& Kumar (2013) about the results of the influence of teacher competence and teacher job satisfaction.

\section{The relationship between teacher job satis- faction and teacher performance}

Based on the regression analysis results above, it shows the effect of teacher job satisfaction on the performance of outstanding school teachers in Banjar Baru city. This can be seen from the correlation of 0.664 with a significant level of $0.000<0.05$ and the correlation result of " 0.05 " than $\mathrm{H} 0$ rejected, which means there is a positive and significant influence between teacher job satisfaction on teacher performance (Ismaya., 2018). Teacher performance is one of the determining factors in achieving educational goals. Teacher performance can be high if the teacher's competence is also adequate, resulting in high job satisfaction. A teacher's level of satisfaction can impact 
a teacher's performance and the institution in which he or she works. The results of this study are also in line with previous research belonging to Haryanto et al. (2020), Ostroff (2013), Stringer et al. (2011), and Chamundeswari (2013) that revealed the results of the same research on the influence of teacher satisfaction and performance variables.

\section{The relationship between teacher job satis- faction and teacher performance}

Based on the regression analysis results, the influence of the principal's leadership style on the job satisfaction of outstanding school teachers in Banjar Baru city. This can be seen from the correlation of 0.664 with a significant level of $0.000<0.05$ and the correlation result of $<0.05$ ), then $\mathrm{H} 0$ rejected, which means there is a positive and significant influence between the principal's leadership style on teacher job satisfaction. The results of the analysis that the principal's leadership style affected the continuity of teacher job satisfaction. Teachers will feel valued and considered if the principal is wise and fair in determining school policy. Teacher satisfaction can be achieved from that feeling of respect and concern. This is in line with the most extensive research (Shibru \& Daeshan, 2011) result of my research indicating a high correlation between components of transformational leadership with subordinate job satisfaction and the summated transformational leadership, which means that one of the leadership styles affects the performance of its workers, as well as research from Givens (2008), Nemanich \& Keller (2007), and Aprisal et al. (2013) the same thing about the effect of the variable.

\section{The effect of teacher competence on teacher performance}

Based on the regression analysis results above, it shows the influence of teacher competence on the performance of outstanding school teachers in Banjar Baru city. This can be seen from the correlation size of 0.850 with a significant level of $0.000<0.05$ and the correlation result of " 0.05 " than $\mathrm{H} 0$ rejected, which means there is a positive and significant influence between teacher competency teacher performance. The teacher's performance can be reflected in his or her duties as a teacher and acting administrator of teaching activities. Teacher performance can be seen in the activities of planning, implementing, and assessing the teaching-learning process whose intensity is based on the teacher's work ethic and professional discipline. Competence is defined as a collaboration or the result of cooperation between a person's talents and abilities (Robbins, 2013). This competency consists of pedagogical competencies, professional competencies, personality competencies as well as social competencies. With this competency, teachers will find it easier to know each character of their students to achieve the educational objectives properly. The results of this study are following previous research: Ningrum (2016), Husni (2014), Yani (2017), Sonedi (2016), Prasanti (2014), Arifin (2015) the relationship between the variables above.

\section{The influence between principal leadership style on teacher performance through the teacher competency and teacher satisfaction}

Analysis of the influence of the principal's leadership style on teacher performance through teacher competence and teacher satisfaction is through direct influence coupled with indirect influence, namely direct influence of 0.027 and indirect influence of 0.047 . Indirect influence $>$ the value of direct influence. This shows that indirectly the principal's leadership style through teacher competence and teacher satisfaction has a significant influence on teacher performance. This can also be seen from the total number of direct and indirect correlations of 0.074 with a significant level of $0.000<0.05$ and the correlation result of $<0.05)$ then $\mathrm{HO}$ is rejected, which means there is a positive and significant influence between the influence of the principal's leadership style on teacher performance through teacher competency and teacher satisfaction.

The principal's leadership style will influence a working behavior for the teachers in the school so that the teachers will have certain competencies that are needed because leadership style will contribute either consciously or unconsciously to the ability or competence that a teacher must-have in the institution 
(Northouse, 2007) leadership is a particular individual process of influencing other individuals to achieve a common purpose. When the teacher has the necessary competencies to carry out his work, then indirectly will form a good performance behavior in the organization. Good behavior in work will provide job satisfaction, both externally and internally, to influence the perpetrators (teachers). This study's results are also following what is said by Pianda (2018) in a book that she wrote.

\section{The influence between teacher work culture on teacher performance through teacher competen-cy and teacher satisfaction}

Analysis of teacher work culture's influence on teacher performance through teacher competence and teacher satisfaction is through direct influence coupled with the indirect influence of 0.137 and indirect influence of 0.102 . The indirect influence $>$ the value of direct influence. This shows that indirectly X2 through $\mathrm{Z} 1$ and $\mathrm{Z} 2$ have a significant influence on $\mathrm{Y}$. This shows that indirectly the teacher's work culture on teacher performance through teacher competence and teacher satisfaction has a significant influence on teacher performance. It can also be seen from the total number of direct and indirect correlations of 0.239 with a significant level of $0.000<0.05$ and the correlation result of <0.05) then $\mathrm{HO}$ is rejected, which means there is a positive and significant influence between the influence of teacher work culture on teacher performance through teacher competence and teacher satisfaction. Good work culture is formed from the behavior of employees who have: Integrity, professionalism, Innovation, Responsibility, and Exemplary that will not be realized when the employees do not master the expected competencies (Nawawi, 2003). Work Culture is a habit repeated by employees in an organization. The violation of this habit is indeed no firm sanction. Still, the organization's perpetrators morally have agreed that the habit is a habit that must be obeyed to carry out the work to achieve the goal. The results of this study reinforce Bateman and Organ's (1993) statement, which stated that an employee who is satisfied with his work would show a good attitude as reciprocity towards the organization that has given satisfaction to him. This is part of the work culture mentioned by Luthans (2006) that aspects become elements, components, or subsystems of organizational behavioral science. The results of this study are also in line with the results of previous research, such as Hendrawan (2010) and Sarjono et al. (2012), which reveal the same results about the influence between teacher work culture variables on teacher performance through teacher competence and teacher satisfaction.

\section{The influence between Principal Leadership Style on Teacher Job Satisfaction through Teach-er Competency}

Analysis of the principal's leadership style on teacher job satisfaction through teacher competency is through direct influence coupled with an indirect influence of 0.063 and an indirect influence of 0.435 . Indirect influence > the value of direct influence. This shows that indirectly the principal's leadership significantly influences teacher performance on teacher job satisfaction through teacher competency. This can also be seen from the total number of direct and indirect correlations of 0.498 with a significant level of $0.000<0.05$ and the correlation result of $<0.05$ then $\mathrm{HO}$ is rejected, which means there is a positive and significant influence between the influence of the principal's leadership style on teacher job satisfaction through teacher competency. The principal's main function as the educational institution leader is to create a teaching situation so that teachers can teach and students can learn well. The ability of one to lead is very influential in improving the competence of its employees. Subordinate-superior communication is an important influence on job satisfaction in the workplace (Zainal, 2005) that broad leadership style will include the process of influencing in determining organizational goals, motivating followers to achieve goals, influencing them into the achievement of events of their followers, organizing and activities to achieve goals, maintaining cooperation and group work relationships, gaining support and cooperation from people outside the group or organization.

The sense of comfort in the work and the appreciation, in this case, can be interpreted as the internal job satisfaction factor. Davis 
(1989) defines job satisfaction as a set of employees' feelings about whether or not their work is enjoyable. Meanwhile, King jr et al. (2009), the satisfaction of an employee in an organization will arise if there is no gap between what is desired and what is accepted.

The longer the distance between what is desired and what employees receive in an organization, the more greedy, the better will be. Employee job satisfaction will arise if disruptive or inhibiting factors such as employment character, peers, working conditions, salaries, wages, promotion, leadership, and fairness of employee rights can be met following expectations. All employees working in an organization will generally undergo recruiting, selection, placement, and career improvement according to the programmed path. In this selection process, accepted employees usually want a high career level, a fair payroll system (Stringer et al., 2011), and humane leadership treatment is the hope during work. During work, an employee can feel satisfied, even very satisfied with one particular aspect, but very likely dissatisfied with one or more aspects of the other. The results of this study are also in line with others research: Sartika (2010), and Evanita et al. (2015).

\section{The influence between Teacher Work Culture on Teacher Job Satisfaction Through Teacher Competency}

Analysis of teacher work culture on teacher job satisfaction through teacher competency is through direct influence coupled with the indirect influence of 0.276 and indirect influence of 0.393 . Indirect influence $>$ the value of direct influence. This shows that indirectly the teacher's work culture towards teacher job satisfaction through teacher competence. This can also be seen from the total amount of direct and indirect correlation of 0.669 with a significant level of $0.000<0.05$ and the correlation result of $<0.05$ ) then $\mathrm{HO}$ is rejected, which means there is a positive and significant influence between the influence of teacher work culture on teacher job satisfaction through teacher competency. The teacher's work satisfaction is related to the suitability between the teacher's expectations and the reality they get. Job satisfaction is a positive or pleasant state of one's emotions that results and assesses a job or work experience. Umar (2001) explained that job satisfaction is an assessment or reflection of the feeling of work towards his work. This is seen in the worker's positive attitude towards his work and everything his work environment faces. This research is also on the tinges of research belonging to Taufiq, Heru, \& Wahyono (2016) Haryanto, Dewi, \& Fatonah (2020), which states the same thing.

\section{Conclusion and Recommendation}

The findings according to the focus of the study can be concluded that:

The applied school autonomy includes, (1) optimizing performance through teacher discipline with fingerprint online attendance; (2) managing learning resources by using libraries and computer rooms as learning resources and extracurricular spaces as places to foster students' interests and talents; (3), the professionalism of education personnel, namely teachers who teach following the ability to educate in special education through training, coaching and educational equality, as well as facilities and infrastructure that meet the needs of students; (5) special services for parents and new students in accessing education.

Implementation of learning through innovative strategic strategies in the 2013 curriculum which was developed using educational programs for blind students; and the role of the teacher; as a modifier, facilitator and mentor and motivator as well as conveying messages in learning media (Dalle \& Mutalib, 2018). Career guidance through further education and future careers.

Implementing participatory decision-making policies through (1) mentoring parents and communities, namely by assisting with active communication and community assistance through committees; (2) school decision making through self-development activities, admission of new students, student graduation, and determining KKM. Activity fund reporting; (3) participatory policy decisions include; (a) a school development plan by producing quality graduates, religious who are faithful and devout, honest, tolerant, disciplined, hard work, creative, independent, democratic, love the country, are friendly, love peace, care for the 
environment, care socially and are responsible, as well as having a creative economy and entrepreneurial skills as a provision for independence in society and to continue to a higher level; (b) establishing disciplinary rules with punishment and reward for all school members; (c) understanding parents and society about children with special needs and access to special education for students with visual impairments.

Achievement of the quality of education in schools at (1) academic quality by successfully passing $100 \%$ of students and (2) non-academic quality successfully by obtaining achievements in every sport and literacy abilities of students.

\section{Acknowledgment}

The author thanked the Head of the Banjar Regency Education Office, the school principal and staff at SLB-A Negeri 3 Martapura and all the teaching staff at Lambung Mangkurat University.

\section{References}

Adha, R., Qomariah, N., \& Hafid, A. (2019). The influence of work motivation, work environment, work culture on the performance of employees of the social service in Jember Regency. Jurnal Penelitian Ipteks, 4(1), 47-62.

Adriana, D. W. (2014). The effect of leadership style and interpersonal communication on teacher performance. Democratia , 1(2), 1-10.

Afandi, P., \& Supeno, B. (2016). The influence of competence, organization culture and work environment to teacher's performance as well as its implication on Grad Competence of State Senior Islam Schools on Padang City. International Journal of Business and Management, 11( 5), 112-119.

Akram, M., Malik, M. I., Anwar, M., \& Ahmad, F. (2015). Relationship of teacher competence with professional commitment and job satisfaction at secondary level. AYER, $4,58-70$.

Aprisal, Dwi Fitri Puspita, \& Ice Kamela. (2013). The influence of organizational culture, principal managerial skills and job satisfaction on the performance of public high school teachers in Kerinci district. Jurnal Program Pascasarjana, 3(2), 11-18.

Arianto, D. A. (2013). The influence of discipline, work environment and work culture on the performance of teaching staff. Jurnal Economia, 9(2), 191-200.
Arifin, H. M. (2015). The influence of competence, motivation, and organisational culture. International Education Studies, 8(1), 38 - 45.

Arifin, M. H. (2015). The influence of competence, motivation, and organisational culture to high school teacher job satisfaction and performance. International Education Studies, 8(1), 38-45.

Artaida, S. (2013). The relationship between school principal supervision, work culture, and work motivation with the performance of private elementary school teachers in Medan Petisah District, Medan City. Medan: Tesis UNIMED.

Banani, M. t. (2017). The influence of principal leadership on teacher competence in realizing learning effectiveness. Jurnal Pendidikam Uniga, 11(1), 67-76.

Baroroh, N. (2013). Analysis of the effect of intellectual capital on the financial performance of manufacturing companies in Indonesia. Jurnal Dinamika Akutansi, 5(2), 117-122.

Basri, A. (2017). Pengaruh etos kerja dan budaya kerja islami terhadap kinerja guru di SMA Negeri 1 Ajangal. Makasar: Univeritas Islam Negeri Alauddin Makassar.

Bogler, R. (2001). The Influence of Leadership Style. Educational Administration Quarterly, 37(5), 662-683.

Brahmasari, I. A., \& Suprayetno, A. (2008). The influence of leadership work motivation and organizational culture on employee job satisfaction. Jurnal Manajemen dan Kewirausahaan, 10(2), 124-135. doi:https://doi.org/10.9744/jmk.10.2.pp.\%20124-135

Chamundeswari, J. S. (2013, Mei). Job satisfaction and performance of school teachers. international journal of academic research in business and scial sciences, 3(5):hlm. 423, (Online), dalam HR MARS (Exploring Intellectual Capital). Retrieved from https://pdfs.semanticsch: https://pdfs.semanticscholar.org/6b37/a469336c20400 8e56ad690aaf9d6b50414d7.pdf.

Dalle, J., \& Mutalib, A. A. (2018). The impact of technologies in teaching interaction design. Journal of Advanced Research in Dynamical and Control Systems, 4(special issue), 17791783.

Dalle, J., Haderani, \& Ulfah, R. (2010). The influence of interest, teachers, facilities and infrastructure, on the ability of students to calculate the volume and area of the geometry. Darul Ulum: Junal Ilmiah keagamaan, Pendidikan, dan Kemasyarakatan, 5(10), 3-24.

Davis, K. \&. (1989). Human behaviour at work organization behaviour. New York : Mc Graw Hill International.

Dekawati, I. (2011). Professional teacher development management. Bandung: Resqi Press.

Djafri, N. (2020). The influence of the principal's leadership style and work culture. Jurnal Perndidikan Anak Usia Dini, 940950. 
Evanita, S., Sari, P. I., \& Wardi, Y. (2015). The Influence of Principal Leadership and Teacher Competence on Teacher Performance in the Field of Productive Business Management in Junior High Schools in Jambi City. Jurnal Ilmiah Dikdaya April, 1(1), 1-10.

Gemafle, M., Waimuri, S. P., \& Batlolona, J. R. (2018). Organizational climate of the school and teacher performance improvement in the 21st century. International Journal of Science and Research, 7(2), 119126.

Ghaney, R. A., Antwi, T., \& Ali, H. (2017). School culture and teacher job performance: a comparative analysis of the perception of teaching staff in private and public basic schools in ga south municipality. British Journal of Education, 5(9), 108-121.

Givens, R. (2008). Transformational leadership: The impact on organizational and personal outcomes. Emerging Leadership Journeys, 1, 4-24.

Gobler, B., Bisschoff, T., \& Beeka, A. (2012). Changing perceptions of teachers regarding the importance and competence of their principals as leaders. South African Journal of Education, 32, 40-45.

Gusman, H. E. (2014). The relationship between the principal's leadership style and the performance of teachers in SMP N Palembayan District, Agam Regency. Jurnal Bahana Manajemen Pendidikan, 2(1), 56-62.

Haryanto, A. T., Dewi, S. N., \& Fatonah, S. (2020). Intrinsic job satisfaction mediates the effect of work competence and work environment on performance in primary schools. Jurnal Basicedu, 4(3), 67-72.

Hendrawan. (2010). The influence of training education, job satisfaction and communication on performance through organizational culture in Semarang Regency Government. Bisnis dan Manajemen Unisbank Semarang, 23(3), 45-65.

Herman. (2001). The influence of the principal's leadership on the teacher performance of SMA Negeri 1 Belopa in Luwu Regency. Makasar: UNM.

Heslin, P. A., Latham, G. P., \& Walle, D. V. (2005). The effect of implicit person theory on performance appraisals. Journal Applied Psychology, 842-856.

Shibru, B., \& Darshan, G. M. (2011). Effect of transformational leadership on subordinate job satisfaction in leather companies in ethiopia. International Journal of Business Management and Economic Research,2(5), 284-295.

Husni, Y. (2014). Effect of competence on teacher performance (Case study of SLTP in Sawahlunto city). Universitas Andalas.

Hutabarat, W. (2015). The impact of organizational culture, organizational structure, and job-satisfaction on high school teachers' job-performance. Cakrawala Pendidikan, 3, 90-95.

Ismaya., P. K. (2018). The relationship between job satisfaction, competence, and teacher performance. Jurnal Adminitrasi dan Manajemen Pendidikan, 1(4), 400-409.

Kalkan, U., Fahriye, A. A., Zehra, A. G., Atasoy, R., \& Dagli, G. (2020). The relationship between schooladministrators' leadership styles, school culture, and organizational image. Sage Open, 1-15.

Khoirun, N. F. (2020). The influence of the principal's leadership style and teacher competence on elementary school teacher satisfaction and performance in Bangil sub-district, Pasuruan district. Malang: Muhamadyah University Malang.

King Jr, W., Lahiff, J. M., \& Hatfield, J. (2009). A discrepancy theory of the relationshipbetween communication and job satisfaction This study found moderate differences incorrelations between communication and job satisfaction using a discrepancy framework whenhigh , as opposed to low , valence rewa. Communication Research Reports, 5(1), 37-41.

Kythreotis, A., Pashiardis, P., \& Kyriakides, L. (2010). The influence of school leadership styles and culture on students' achievement in Cyprus primary schools. Journal of Educational Administration, 218-240.

Lubis, A. (2016). The influence of work culture and leadership style on job satisfaction of other administrative employees in the conclusions. Tazkir :Jurnal Penelitian Ilmu-ilmu Sosial dan Keislaman, 2(2), 157-174.

Luthans, F. (2006). Organizational behavior. Yogyakarta: PT Andi. Mahri, A. J. (2014). Principal leadership, its effect on teacher competence, motivation and job satisfaction and its implications for teacher performance. Kontingensi, 1(1).

Miyono, N., \& Makshun, N. (2017). Teacher competency and work culture in shaping the professionalism of madrasah ibtidaiyah teachers in Temanggung district. Jurtnal Manajemen Pendidikan, 6(3), 12-16.

Narsih, D. (2017). The influence of competence and job satisfaction on teacher performance. Utility: Jurnal Ilmiah Pendidikan dan Ekonomi, 94-102.

Nawawi, H. (2003). Human Resource Management. Yogyakarya: UGM Press.

Nemanich, L., \& Keller, R. T. (2007). Transformational leadership in an acquisition: A field study of employees The Leadership Quarterly. The Leadership Quarterly, 18, 49- 68.

Ningrum, K. s. (2016). The influence of teacher competence on teacher performance at SMP 6 Singaraja. Jurnal Program Studi Pendidikan Ekonomi (JPPE), 7(2), 85-91.

Normianti, H., Aslamiah, A., \& Suhaimi, S. (2019). Relationship of transformational leaders of principal, teacher motivation, 
teacher organization commitments with performance of primary school teachersin labuanamas selatan, indonesia. European Journal of Education Studies, 123 - 141.

Northouse, P. G. (2007). Leadership: theory and practice. (4th Edition). Thousand Oaks: CA: Sage.

Nurman, M., Yuliejantiningsih, Y., \& Roshayanti, F. (2018). The influence of the principal's participatory leadership and teacher competence on the quality of public junior high schools in Bumiayu sub-district, Brebes district. Jurnal Upgris, 7(3), 112-117.

Ostroff, 2. R. (2013). Relationship between Satisfaction, attitude and performance an organization level analisis. Journal of Applied Psycology, 77(6), 933 - 937.

Pakpahan, G. E., Simanjutak, J., Nababan, S., \& Sudirman, A (2019). The influence of organizational culture, communication and teacher competence on the performance of private high school teachers, Sultan Agung Pematangsiantar. Kinerja, 16(2), 11-16.

Pianda, D. (2018). Teacher competence, work motivation, leadership of the principal. Sukabumi: Jejak.

Prasanti, A. (2014). The influence of school principal leadership, teacher competence, and work environment on school productivity. Journal of Acounting and Bussiness Education, $8(2), 110-115$.

Purwoko, S. (2018). The influence of principal leadership, teacher commitment, teacher work discipline, and school culture on vocational school teacher performance. Jurnal Kuntabilitas Manajemen Pendidikan, 6(2), 149-162.

Rafiie, D., SIdris, S., \& Aziz, N. (2018). The influence of competence, leadership style, work culture and work environment on employee job satisfaction and their impact on the performance of the office employees of the Ministry of Religion, West Aceh Regency. Jurnal Magister Manajemen Fakultas Ekonomi Dan Bisnis Unsyiah, 36-45.

Rahardjo, S. (2014). The effect of competence, leadership and work environment towards motivation and its impact on the performance of teacher of elementary school in Surakarta city, Central Java, Indonesia. International Journal of Advanced Research in Management and Social Sciences, 3(6), 59-74.

Resawati, R., \& Larasati, I. (2016). The influence of principal leadership, teacher competence and compensation on teacher performance. Jurna Stiepas, 10(2), 132-148.

Ridho, T., Wulan, H. S., \& Wahyono, E. H. (2016). The influence of organizational culture, principal leadership, and teacher competence on teacher performance, with job satisfaction as an intervening variable. Jurnal Bisnis dan Manajemen Unpad, 2(3), 113-117.

Robbins, S. P. (2013). Organizational Behavior Edition 15. New Jersey: Pearson Education.
Robins, S. P. (2006). Organizational behavior. Jakarta: Prehallindo.

Saputra, E., Sumadi, \& Miswar, D. (2015). The influence of the principal's leadership style and work motivation. Jurnal Geografiu Universitas Lampung.

Sari, F. M. (2013). The influence of competence and work environment on job satisfaction and teacher performance in SD Negeri Gondang Mojokerto District. DIE, Jurnal Ilmu Ekonomi \& Manajemen, 9(2), 137 - 153.

Sarjono, H., Sanny, L., \& Cahyo, S. (2012). Haryadi Sarjono, Lim SReview of Organizational Culture, Style Leadership Affect Job Satisfaction on Employee Performance at PT. Motor Nasional. Jakarta Based Approach SPSS vs LISREL Global Network Journal, 5(1), 36-57.

Sartika. (2010). Analysis of the effect of work discipline, work competence on teacher task performance with intrinsic job satisfaction as an intervening variable (study at PT. Coca Cola Sangatil Indonesia (Central Java). Jurnal Bisnis \& Manajemen, 3(2), 81-93.

Sekaran, U. (2006). Research methodology for business. Jakarta: Salemba.

Sel, S. K. (2012). Teaching competency and job satisfaction among high school teachers. A study. Voice of Research, $1(2), 16-20$.

Setiyati, S. (2014). The influence of principal leadership, work motivation, and school culture on teacher performance. Jurnal Pendidikan Teknologi dan Kejuruan, 200-206.

Shamaki, E. B. (2015). Influence of Leadership Style on Teacher's Job Productivity in Public Secondary Schools in Taraba State, Nigeria .Journal of Education and Practice, 6(10), 200 $-203$.

Shukla, S. (2014). Teaching competency, professional commitment and job satisfaction- A study of primary school teachers. IOSR Journal of Research and Method in Education, 4 , 44 - 65.

Sing, J., \& Kumar, A. J. (2013). Relationship between teaching competence and job satisfaction: A study among teacher educators working in self-financing colleges in Uttar Pradesh, India. Indian Journal of Applied Research, 3(2), 82 $-84$.

Sonedi. (2016). The relationship of principal leadership and teachers' attitude to their work with the teacher's professional competence. Anterior Jurnal, 16(1), -115-120.

Stringer, C., Didham, J., \& Theivananth, P. (2011). Motivation, pay satisfaction, and job satisfaction of front-line employees. Econ Papers, 161-179.

Sujarwo. (2012). Character education-based boarding school management (Multi case study in MA Unggulan Amanatul Ummah Surabaya, Ar-Rohmah Dau High School Malang and MA Nurul Jadid Paiton Probolinggo. Malang: Universitas Negeri Malang. 
Supriadi, M. D. (2014). The difference in the performance of public SD teachers in Selat District is based on the leadership style of the school principal and the school climate. Paradigma, 9(1), 11-16.

Suryani, S. (2013). The influence of work culture on teacher performance in the teaching and learning process of high school and vocational schools in Prambanan district. Yogyakarta: Universitas Negeri Yogyakarta.

Tafqihan, Z., \& Suryanto. (2014). The influence of teacher competence on professional commitment and its impact on the performance and job satisfaction of junior high school and MTs mathematics teachers. JURNAL Riset Pendidikan Matematika, 1(2), 11-17.

Talimbo, D. (2013). The influence of work culture, work environment, and job satisfaction on work performance of organic employees is still common at Tobelo. Jurnal Riset Bisnis Dan Manajemen, 1(3), 15-21.

Tambingon, H. N. (2018). The Influence of Principal Leadership Style and Teacher Work Motivation on the Performance of Certified Teachers at SMA Negeri Kotamobagu, North Sulawesi, Indonesia. Journal of Education and Learning, 12(3), 357-365.
Tsay, Y. (2011). Relationship between Organizational Culture, Leadership Behavior and Job Satisfaction. BMC Healt Services Research, 11, 98.

Turan S, \& Bektas F. (2013). The Relationship Between School Culture and Leadership Practices. Egitim ArastirmalariEurasian Journal of EducationalResearch, 155-168.

Wawan Wahyudin. (2017). Headmaster Leadership and Teacher Competence in Increasing Student Achievement in School. International Education Studies, 10(3), 11-17.

William, S. (2005). The Competence, Motivation and Facilities Affect toward Performance and Increasing TheQuality of Education in Australia College. Journal Human Resource Management.

Xenikou, A. (2017). Transformational Leadership, Transactional Contingent Reward, and Organizational Identification: The Mediating Effect of Perceived Innovation and Goal Culture Orientations. frontiers in psychology, 8, 1-13.

Yani, D. (2017). Leadership of school principals in fostering teacher pedagogical competences at SMA Negeri 1 Unggul Darul Imarah, Aceh Besar District. Banda Aceh: UIN ArRaniry.

Zainal, V. R. (2005). Leadership and organizational behavior. Jakarta: PT Raja Grafindo Persada. 